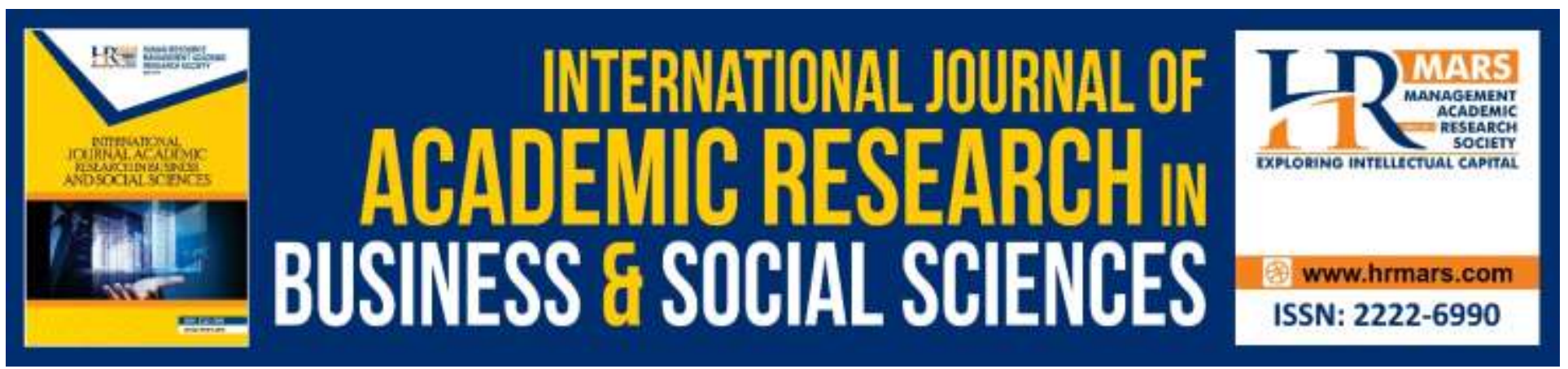

\title{
Determinants of Co-operatives' Dividend Payout in Malaysia
}

\section{Nooraslinda Abdul Aris, Norashikin Ismail, and Rohana Othman}

To Link this Article: http://dx.doi.org/10.6007/IJARBSS/v10-i13/6886

DOI:10.6007/IJARBSS/v10-i13/6886

Received: 22 December 2019, Revised: 01 January 2020, Accepted: 22 January 2020

Published Online: 13 February 2020

In-Text Citation: (Aris et al., 2020)

To Cite this Article: Aris, N. A., Ismail, N., \& Othman, R. (2020). Determinants of Co-operatives' Dividend Payout in Malaysia. International Journal of Academic Research in Business and Social Sciences, 10(13), 30-40.

\section{Copyright: (C) 2020 The Author(s)}

Published by Human Resource Management Academic Research Society (www.hrmars.com)

This article is published under the Creative Commons Attribution (CC BY 4.0) license. Anyone may reproduce, distribute, translate and create derivative works of this article (for both commercial and non-commercial purposes), subject to full attribution to the original publication and authors. The full terms of this license may be seen

at: http://creativecommons.org/licences/by/4.0/legalcode

Special Issue: Upstream Research in Business and Management: Towards Socio-Economic Prosperity, 2020, Pg. 30 - 40

Full Terms \& Conditions of access and use can be found at http://hrmars.com/index.php/pages/detail/publication-ethics 


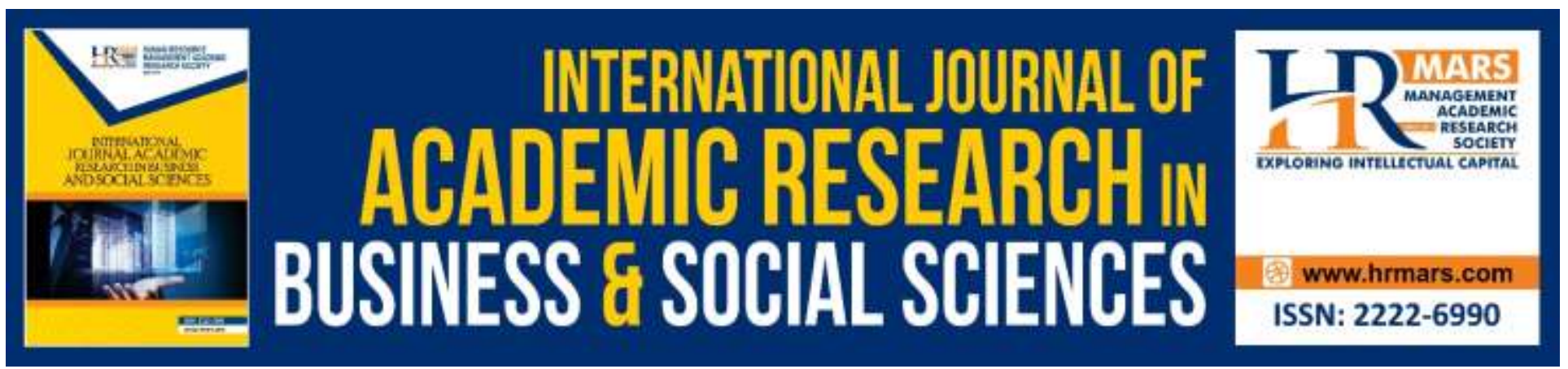

\title{
Determinants of Co-operatives' Dividend Payout in Malaysia
}

\author{
Nooraslinda Abdul Aris, Norashikin Ismail, and Rohana Othman \\ Universiti Teknologi MARA Malaysia \\ Email: nooraslinda@salam.uitm.edu.my
}

\begin{abstract}
The co-operative sector in Malaysia is targeted to be a pivotal contributor to the economy. As community-based organizations, co-operatives are not only concerned about the businesses bottom lines, but also about fulfilling the members' needs and improving the communities' quality of life. In a nutshell, the co-operative business model is aimed at enhancing the socio-economy of their members and the local community that cannot be measured solely by financial statements and standard financial ratios. Co-operatives should attempt to measure the member-level returns, and dividend payment is one of the measures. Payments of dividend highlight the 'member-owner' role of co-operative membership. The dividend payment provides incentives for external investor or members to leave funds in the co-operative. This payment in return will help the co-operatives in getting the supplies of funds from members to invest in profit generating project or assets. This study examines factors affecting dividend payout of 360 leading co-operatives in Malaysia. Both financial and non-financial parameters were assessed which were then translated as formative determinants of dividend payout. Findings showed that return on assets, both co-operatives financial and nonfinancial parameters, age and size have a significant influence towards the dividend payout among Malaysian co-operatives. This result provides consistent evidence that dividend payout decisions in the co-operatives are similar to the profit-oriented organizations. The positive association between all performance measures and dividend support the agency cost and signaling theories of dividend policy, while the unexpected results of a negative relationship between age and dividend payout provide support for legitimacy theory.
\end{abstract}

Keywords: Dividend Payout, Performance, Co-Operative

\section{Introduction}

The co-operatives have long been recognized to play an important role in society, particularly in enhancing the members' standards of living, predominantly the low-income earners, as well as the whole community (ICA, 2013; Marwa \& Aziakpono, 2015; Karageorgopoulos, 2014) . Globally, the cooperative sector counts over one billion members existed in over 65 countries (ICA \& Euricse, 2014). The world's 300 largest co-operatives reported revenues more than $\$ 2$ trillion while providing more 
INTERNATIONAL JOURNAL OF ACADEMIC RESEARCH IN BUSINESS AND SOCIAL SCIENCES

Vol. 10, No. 13, Special Issue: Upstream Research in Business and Management: Towards Socio-Economic Prosperity. 2020, E-ISSN: 2222-6990 @ 2020 HRMARS

than 100 million jobs, 20\% more than multinational corporations (ICA, 2013). Co-operatives are believed to provide a suitable alternative for society in offering goods and services rendered at a reasonable price to improve the economy and life quality.

In Malaysia, co-operatives are positioned as an essential mechanism for socio-economic growth and development. The Government had in January 2004 launched the first National Cooperative Policy (NCP) covering the period of 2002-2010 to guide co-operatives to improve their performance (International Business Review, 2011; Shbeilat, Harasees 2018). The NCP takes a step further by setting forth plans to strengthen the role of co-operatives in driving the economy to highvalue-added and high-income and adequately maintaining the economic stability of Malaysia. The ultimate objective for the co-operative sector is to increase its contribution to the national product. The second NCP (2012-2020) outlines four primary goals for co-operatives namely; contribute $5 \%$ to the National Product by 2013 and $10 \%$ by 2020; improve the socio-economic status of members; increase concern for the environment and be responsible corporate citizens \{Formatting Citation\}.

Despite the government support, co-operatives in Malaysia have encountered many shortcomings. A study on Malaysian co-operatives from 2002 to 2010 highlighted size, capital, structure, entrepreneurial culture and good governance as issues that need to be overcome to bring the success of co-operatives (Bidin, 2007; Othman \& Kari, 2008; Hussin \& Hafit, 2018). Responding to the issues, the government reinforced the role of the Malaysia Co-operative Societies Commission (MCSC) in 2008 (established in 1922) as the co-operatives sole authority with the primary objective of stimulating the strong and robust development of co-operatives. The MCSC later issued the Top 100 Co-operatives Index in acknowledging performing co-operatives contributions which positively affect the nations' economy.

Performing co-operatives bring about many obvious benefits to their members such as sharing costs or financial dividends. Co-operatives resemble firms with regards to the ability to pay out dividends, but they also have elements of a non-profit entity. Mayo (2011) stated that the Cooperative Performance Committee had developed a framework for measuring co-operative performance grounded on a set of common indicators and benchmarks based on shared data. These indicators are of two kinds - financial and non-financial indicators and are in line with the International Co-operative Alliance (ICA) standard guideline.

Studies on factors determining dividend among co-operatives are thus far limited. Most researchers discussed dividend concerning its payout policy, performance, and governance among profit-oriented organizations (Farooq, Shehata, \& Nathan, 2018; Gugler, 2003; McCluskey, Burton, \& Power, 2007). Few studies examined determinants of dividend payout of a firm (Al-Kuwari, 2009; Arko et al., 2014; Hutagalung, Yahya, Kamarudin, \& Osman, 2013). Prior research on co-operatives' dividend varies and in general, focused on the specific function of co-operatives. This study, therefore, without limiting to function, examine factors influencing dividend payout of 360 performing co-operatives residing in Malaysia.

\section{Literature Review}

The agency theory assumes that there is an inherent conflict between the interests of a firm's owners and its management (Jensen \& Meckling, 1976). Accordingly, management in all organizations tends to behave opportunistically. It is suggested that the board members should be independent of management with the primary role of ensuring managerial compliance; to monitor and if necessary, 
INTERNATIONAL JOURNAL OF ACADEMIC RESEARCH IN BUSINESS AND SOCIAL SCIENCES

Vol. 10, No. 13, Special Issue: Upstream Research in Business and Management: Towards Socio-Economic Prosperity. 2020, E-ISSN: 2222-6990 @ 2020 HRMARS

control the behavior of management to ensure it acts in the shareholders' best interests. Agency theory in co-operatives is considered complex as members are also the owner/principal and the entities main objective is to maximize the members benefit, instead of profit maximization. As such, adequate monitoring or control mechanisms (agency cost) need to be established to protect shareholders' interest from management's misbehaviors. Empirical evidence proves that agency costs are significantly higher in co-operatives than in limited companies (Syrjä, Sjögren, \& Tuominen, 2012) due to members having insufficient chances to monitor or control the opportunistic management behavior. Thus, dividend payout serves as a control mechanism.

Paying dividends may be one way to reduce conflicts of interest as it impedes management from spending frivolously and thus curtail suboptimal investment. The dividends exposed firms to more frequent monitoring by the markets as it increases the chances of issuing new common stock as well as reducing potential over-investment by management (Arko et al., 2014; Gugler, 2003). It also means the firm can disburse the excess cash that otherwise could be spent on unprofitable projects. This model can be quite easily extended to co-operatives and suggests similarly that the primary role of the board is to ensure managers act in the best interests of the co-operatives' members.

Appraisal of firm performance as indicators of strong values is crucial for control purposes. Hind (1999) highlighted the dilemma facing co-operatives in terms of selecting the appropriate performance measures. Co-operatives, having a member-owner relationship, may use profitability, growth, dividends, share prices, assets and return on capital as performance indicators.

\section{Dividend Payout}

A dividend is simply the money that a company pays out to its shareholders from the profits it has made either by cash or by issuing additional shares. Dividend in co-operatives is regarded as benefit allocation to members that may reduce efficiency losses from overproduction (Emmons \& Schmid, 2002). Researchers always contemplate about the dividend payment and the need to pay attention to dividends (Farooq et al., 2018; Noordin, Rajaratnam, Anuar Said, Mohd Hanif, \& Juhan, 2012). Traditionally, finance scholars emphasize explanations for dividends that are based on the desire to communicate information to shareholders or to satisfy the demand for payout from heterogeneous dividend clienteles (Arko et al., 2014). Payments of dividends are usually influenced by certain factors namely the dividend policy, net profit, cash flow, debt-equity ratio, sales growth and size of a firm.

Dividend payout is a reliable proxy to measure firm performance as management would consider current and future profits before deciding on the amount of payout (Hutagalung et al., 2013). Dividends are important to shareholders and potential investors in showing the earnings that a company is generating. High dividend payout firms tend to experience strong future earnings, and historical evidence strongly suggests that expected future earnings growth is fastest when current payout ratios are high and slowest when payout ratios are low (McCluskey et al., 2007).

Dividends can influence shareholders' wealth by providing information to investors or through wealth redistribution among shareholders (Al-Kuwari, 2009). The dividend policy can influence capital structure or investment decisions that may enhance the firm's value (Ofori-Sasu, Abor, \& Osei, 2017). Such policy also effects one or more of imperfections in the real world such as information asymmetry and agency problems, as well as taxes and transaction costs. 
INTERNATIONAL JOURNAL OF ACADEMIC RESEARCH IN BUSINESS AND SOCIAL SCIENCES

Vol. 10, No. 13, Special Issue: Upstream Research in Business and Management: Towards Socio-Economic Prosperity. 2020, E-ISSN: 2222-6990 @ 2020 HRMARS

An organization's form and size also determine its economic success. Among the largest and profitable firms, dividend payout tends to be stable (Al-Kuwari, 2009; Hutagalung et al., 2013). In cooperatives, the dividend payout is important as members are the capital contributors. Besides benefiting from products and services offering, the dividend is a necessity in ensuring the cooperatives longevity. Prior studies on co-operatives dividend vary from modeling pricing and dividend policy to highlighting the co-operative financial structure differences, assessing the dividend and profit allocation practices and asserting the importance of membership structure (Burger, 2013; Emmons \& Schmid, 2002; Noordin et al., 2012). Hence, it is expected that financial and non-financial factors along with other factors will influence the co-operatives' dividend payout.

\section{Performance Measurement}

Firm performance can be viewed as how well an entity enhances its shareholders' wealth and the capability of generating earnings from the capital invested by shareholders. This study uses performance measurement consist of financial factors (FF) and non-financial factors (NFF) as defined by the MCSC. An alternative performance measure using return on assets (ROA) is also used (Marwa \& Aziakpono, 2015; Noordin et al., 2012; Tariq \& Abbas, 2013).

The accounting-based measures of financial factors are argued as sufficient performance predictors. Traditionally, financial ratios measuring profitability, liquidity, and solvency prevailed as the most significant indicators (Hutagalung et al., 2013). These ratios have been widely used exclusively in the corporate realm as health monitoring tools as well as predicting business failure. In assessing general business, the current ratio and debt ratios are used in measuring a company's shortterm liquidity and long-term solvency, while ROA is used to evaluate the assets productivity. Marwa and Aziakpono (2015) for instance use ROA, financial sustainability, and technical efficiency to determine the performance of Tanzanian saving and credit co-operatives.

Non-financial factors provide qualitative information on business performance. For cooperatives, the measures include longevity and growth in membership, active participation and member satisfaction (Aaijaz, Mohamed Salleh, \& Ibrahim, 2012). Other non-financial factors such as regulatory compliance, contribution to trust funds, environment management, and social responsibility too are considered important. A positive relationship was found between corporate social responsibility (CSR) and the performance of 280 firms in Finland covering financial performance, employee commitment and corporate reputation (Syrjä et al., 2012). The CSR of a cooperative has been found to affect the customers'/members' satisfaction which translated into better performance (Aaijaz et al., 2012). Corporate governance structure should maximize coordination and motivation, or at the least, possible minimize transaction costs for members and their co-operative (Burger, 2013).

Based on the above, the study hypothesizes the following:

$\mathrm{H}_{1}$ : $\quad$ There is a positive relationship between financial factors (FF) and co-operative dividend payout

$\mathrm{H}_{2}$ : There is a positive relationship between non-financial factors (NFF) and co-operative dividend payout

$\mathrm{H}_{3}$ : There is a positive relationship between return on assets (ROA) and co-operative dividend payout 


\section{Co-operative Characteristics}

\section{Size of Co-operatives}

Firm size is a significant explanatory variable. Studies indicated that large firms distribute a higher amount of their net profits as cash dividends, than do small firms (Mahdzan, Zainudin, \& Shahri, 2016; Redding, 1997). Larger companies are more likely to increase their dividend payout to decrease agency costs (Gugler, 2003). Dividend payout can help to indirectly monitor the performance of managers in large firms due to information asymmetry which increases the ownership dispersion and hence, reducing the shareholders' ability to monitor the firm internal and external activities. Noordin et al. (2012) on the other hand find that micro co-operatives in Malaysia paid the highest average dividend while the credit co-operatives having a sizeable number of shares and subscriptions are observed to have the lowest average dividend payout ratio. Based on the inconsistent evidences it is therefore hypothesized:

$\mathrm{H}_{4}$ : There is a relationship between size and co-operative dividend payout

\section{Age of Co-operative}

Age is typically measured by the number of years a firm has been established. Newer firms are more likely to be concerned with resolving critical strategic issues, such as, choosing a competitive strategy, selecting strategy implementation methods, and establishing strategic control mechanisms (OforiSasu et al., 2017). Managers of newer firms may have less knowledge of external environmental factors when compared with executives of older organizations. The year of establishment will affect a co-operative's performance in the sense more time and opportunity are needed to become conversant on the co-operative environment. This study thus hypothesizes the following:

$\mathrm{H}_{5}$ : $\quad$ There is a significant positive relationship between age and co-operative dividend payout.

\section{Method \\ Data Collection}

The sample for this study comprises 360 performing co-operatives which are listed by the MCSC. Although Malaysian co-operatives in classified into nine functions - banking, credit, consumer, services, housing, construction, transportation, plantation, and industrial, the data were further grouped into financial and non-financial based on their primary activities. Data for this study were obtained from the INFOKOP system of MCSC which provides both financial and non-financial data for the year 2010. The dividend payout ratio was used as dependent variable. The independent variables are factors hypothesize to influence the dividend payout of Malaysian co-operatives. They are financial factors (FF), non-financial factors (NFF), and return on assets (ROA). Size measured in total assets and age of the co-operative. The ratios and weight of co-operatives FF as suggested by MCSC consist of current ratio (15\%), debt equity ratio (15\%), gross profit (10\%), net profit (10\%), ROA (10\%), return on equity (5\%), and net tangible asset (5\%); while for the NFF include governance (17\%), services to members (5\%), social responsibility (5\%), and establishment objective (3\%). The total score for each FF and NFF were then factored to $100 \%$. 


\section{Research Model}

The relationship between dividend payout and independent variables of performance, age and size is tested using ordinary least square method. The model for the study is as follows:

$D I V P A Y=\alpha+B_{1} F F+B_{2} N F F+B_{3} R O A+B_{4} S I Z E+B_{5} A G E+\varepsilon$

Where DIVPAY is the co-operative dividend payout, $\alpha$ is the intercept, $F F$ is financial factors, and NFF is non-financial factors. SIZE is the $\log _{10}$ of co-operative total assets, AGE represents the number of year's establishment and $\varepsilon$ is the error term.

\section{Results and Discussion}

\section{Descriptive Statistics}

Descriptive statistics were run grouping the data into financial and non-financial based cooperatives. The statistic shows that the financial-based co-operatives, in general, have been established for a longer period than non-financial based co-operatives with a mean age of 37.3 years. The financial-based co-operatives performed better in both measurements of financial and nonfinancial indicators. The mean ROA, FF and NFF for financial based co-operatives are $0.1762,0.5738$, and 0.2695 respectively in comparison to $0.1606,0.5625$, and 0.2635 for the non-financial based cooperatives. The statistics also show that financial-based co-operatives pay a lower dividend (mean 0.0696) than non-financial co-operatives (mean 0.0804).

\section{Correlation and Regression}

TABLE 1 shows the correlation between dividend payout and variables included in the study and

TABLE 2 presents the results of regression analysis for the association between dividend payout ratio, independent and control variables.

TABLE 1: Pearson Correlation between variables

\begin{tabular}{lrrrrrr}
\hline & DIVPAY & FF & NFF & ROA & \multicolumn{1}{c}{ SIZE } & \multicolumn{1}{c}{ AGE } \\
\hline DIVPAY & 1 & $.201^{* *}$ & $.138^{* *}$ & $.199^{* *}$ & $.123^{*}$ & $-.177^{* *}$ \\
FF & & 1 & $.164^{* *}$ & $.105^{*}$ & -.026 & $.124^{*}$ \\
NFF & & & 1 & -.011 & $.198^{* *}$ & $.123^{*}$ \\
ROA & & & & 1 & .092 & $-.112^{*}$ \\
SIZE & & & & & 1 & $.185^{* *}$ \\
AGE & & & & & & 1 \\
\hline
\end{tabular}

*. Correlation is significant at the 0.05 level (2-tailed). ${ }^{* *}$. Correlation is significant at the 0.01 level (2-tailed). 
TABLE 2: Regression results

\begin{tabular}{|c|c|c|c|c|c|c|c|}
\hline Model & & $\begin{array}{c}\text { Coefficient } \\
\text { s }\end{array}$ & Beta & t-stats & $p$-value & $\begin{array}{c}\text { Toleranc } \\
\mathrm{e}\end{array}$ & VIF \\
\hline \multirow[t]{10}{*}{1} & (Constant) & -.158 & & -3.003 & .003 & & \\
\hline & $\mathrm{FF}$ & .119 & .199 & 3.916 & .000 & .939 & 1.065 \\
\hline & NFF & .259 & .108 & 2.105 & .036 & .926 & 1.079 \\
\hline & ROA & .017 & .142 & 2.818 & .005 & .957 & 1.045 \\
\hline & SIZE & .019 & .135 & 2.626 & .009 & .914 & 1.095 \\
\hline & AGE & -.001 & -.224 & -4.369 & .000 & .925 & 1.081 \\
\hline & $\mathrm{N}$ & 360 & & & & & \\
\hline & $\mathrm{R}^{2}$ & 0.139 & & & & & \\
\hline & Adjusted $\mathrm{R}^{2}$ & 0.127 & & & & & \\
\hline & $\mathrm{F}$ & 11.474 & & & & & \\
\hline
\end{tabular}

The results show that the model is significant at the one percent level $(F=11.474, p=0.000)$ with an adjusted $\mathrm{R}^{2}$ of $12.7 \%$. The result indicates that the age of co-operative is negative and significantly associated with dividend payout ratio. The result also shows that age has the highest beta value $(b=.224)$ indicating that this variable makes the strongest unique contributions to explaining the dividend payout of Malaysian co-operatives when the variance explained by all other variables in the model is controlled for. The negative association between age and dividend payout ratio is however in contradiction to the hypothesis. The negative coefficient means the younger cooperative has a higher dividend payout ratio than the more establish co-operative. The unexpected result perhaps can be explained by legitimacy theory. Co-operative operates on the notion that there is a 'social contract' (Deegan, Rankin, \& Tobin, 2002; Patten, 1991) between the co-operatives and their members in delivering social and economic benefits to members. The management of new or less established co-operative, therefore, may adopt high dividend policy in delivering economic benefits to legitimate their existence. La Porta, Lopez-de-Silanes, Shleifer, and Vishny (2000) also explain the negative association and argued that dividends can substitute for monitoring roles of stakeholders and thus, firms make dividend payments to establish a reputation for acting in the best interests of shareholders. The financial performance measured as ROA shows a positive association with dividend payout. The result is consistent with studies in profit-making organization (Mahdzan et al., 2016; Tariq \& Abbas, 2013). This result is consistent when the performance of co-operatives is measured as an index in both FF and NFF, which are positive and significantly related to dividend payment at one percentage level respectively. Performance measured as FF $(B=.199)$ is, however, has a higher contribution in explaining dividend payout than NFF $(b=.108)$. 
INTERNATIONAL JOURNAL OF ACADEMIC RESEARCH IN BUSINESS AND SOCIAL SCIENCES

Vol. 10, No. 13, Special Issue: Upstream Research in Business and Management: Towards Socio-Economic Prosperity. 2020, E-ISSN: 2222-6990 @ 2020 HRMARS

The other independent variable of size is positive and significantly related to dividend payout. The result is consistent with Redding (1997) who examined the impact of size on the dividend for profit-making organizations. The results show that firm size and liquidity explain the decision of whether to pay dividends well.

\section{Conclusion}

Dividend payment reflects the co-operative performance as an organization that carries socialeconomy objectives pointed towards the company survival using retained earnings. Decisions on dividend payout are vital as they determine what funds to be preserved for investment and what funds flow to shareholders. Furthermore, government and regulators fiscal policies tend to put some restrictions on the amount of dividend a co-operative may pay to ensure sustainability of the cooperative and the sector (Noordin et al., 2012).

Co-operatives constitute an important economic development vehicle in providing products and services, employment, fairer income distribution and potentially contribute to poverty alleviation. It is worth noting that research on co-operatives in Malaysia and other parts of the world has been minimal although reported contributions by co-operatives have been quite remarkable. Research on co-operatives typically deals with issues of governance, dwelling on shortfalls related to boards' size, roles and responsibilities, politicization and excessive control/interference by the government (Othman, Arshad, Aris, \& Arif, 2015). It is time that more research is conducted in assessing the performance, management, and operationalization of co-operatives to understand the third engine of Malaysia's growth better.

This paper examined factors influencing dividend payout for the Malaysian co-operatives. The finding of testing five propositions provides unexpected evidence that after controlling for performance and size, new co-operatives pay more dividend than the established co-operatives. The result of high dividend payout in delivering economic benefits to members provides contributions to the legitimacy theory. Consistent with the study hypotheses, other variables of performance and size are also significantly associated with dividend payout.

In future, this study may be extended to consider other non-financial variables that may influence dividend payout. Variables such as the co-operative sector growth, economic condition, and management ability may be explored for their relationship with dividend payout. As cooperatives exist all around the world, it may also be worthwhile to compare the dividend payout or distribution practices among regions, industries or functions. The unique nature of co-operatives as 'one-member-one-vote' entities with their distinct identity may create more interest in the sector. In retrospect, uplifting the members well-being while helping the local community may be the biggest reason for people joining the co-operatives.

\section{Acknowledgement}

The authors gratefully acknowledge the help of the Research Management Centre (RMC) in providing the Bestari research grant (043/2017), and Universiti Teknologi MARA (UiTM). The authors are also thankful to MCSC for providing the information that was used in this research.

\section{References}

Aaijaz, N., Salleh, M. S. S., \& Ibrahim, M. D. (2012). Cooperative social responsibility: the gap model 
INTERNATIONAL JOURNAL OF ACADEMIC RESEARCH IN BUSINESS AND SOCIAL SCIENCES

Vol. 10, No. 13, Special Issue: Upstream Research in Business and Management: Towards Socio-Economic Prosperity. 2020, E-ISSN: 2222-6990 @ 2020 HRMARS

approach and empirical derivation to members' satisfaction. In 18th IBIMA Conference (pp. 2092-2112).

Al-Kuwari, D. (2009). Determinants of the dividend policy in emerging stock exchanges: The case of GCC countries. Global Economy \& Finance Journal, 2(2), 38-63.

Arko, A. C., Abor, J., Adjasi, C. K. D., Amidu, M., C. Arko, A., Abor, J., ... Amidu, M. (2014). What influence dividend decisions of firms in Sub-Saharan African? Journal of Accounting in Emerging Economies, 4(1), 57-78. https://doi.org/10.1108/JAEE-12-2011-0053

Bidin, Y. H. (2007). Positioning knowledge management as key success factors in the growth of cooperatives in Malaysia. Asian Academy of Management Journal, 12(1), 69-82.

Burger, C. (2013). Membership structure and dividend payout policies at Hungarian co-operative banks. Acta Oeconomica, 63(3), 287-308. https://doi.org/10.1556/AOecon.63.2013.3.2

Deegan, C., Rankin, M., \& Tobin, J. (2002). An examination of the corporate social and environmental disclosures of BHP from 1983-1997. Accounting, Auditing \& Accountability Journal, 15(3), 312343.

Emmons, W. R., \& Schmid, F. A. (2002). Pricing and Dividend Policies in Open Credit Cooperatives. Journal of Institutional and Theoretical Economics, 158(2), 234-255. https://doi.org/10.1628/0932456022975439

Farooq, O., Shehata, N., \& Nathan, S. (2018). Dividend Policy and Informativeness of Reported Earnings: Evidence from the MENA Region. International Review of Finance, 18(1), 113-121.

Gugler, K. (2003). Corporate governance, dividend payout policy, and the interrelation between dividends, R\&D, and capital investment. Journal of Banking \& Finance, 27(7), 1297-1321.

Hind, A. M. (1999). Cooperative Performance-Is There a Dilemma? Journal of Cooperatives, 30-43.

Hutagalung, S., Yahya, M., Kamarudin, F., \& Osman, Z. (2013). The dividend payout policy - A study on Malaysian financial institutions. Pertanika Journal of Social Science and Humanities, 21(S), 127-148.

ICA. (2013). ICA Annual Report 2013.

ICA, \& Euricse. (2014). Exploring the Co-operative Economy: Report 2014.

International Business Review. (2011, January 21). Small but Mighty: Cooperatives and National Development in Malaysia. International Business Review.

Jensen, M. C., \& Meckling, W. H. (1976). Theory of the Firm: Managerial Behavior, Agency Costs and Ownership Structure. Journal of Financial Economics, 3, 305-360.

La Porta, R., Lopez-de-Silanes, F., Shleifer, A., \& Vishny, R. (2000). Investor protection and corporate governance. Journal of Financial Economics, 58(1-2), 3-27.

Mahdzan, N. S., Zainudin, R., \& Shahri, N. K. (2016). Interindustry dividend policy determinants in the context of an emerging market. Economic Research-Ekonomska Istraživanja, 29(1), 250-262.

Marwa, N., \& Aziakpono, M. (2015). Financial sustainability of Tanzanian saving and credit cooperatives. International Journal of Social Economics, 42(10), 870-887. https://doi.org/10.1108/IJSE-06-2014-0127

Mayo, E. (2011). Co-operative Performance. Sustainability Accounting, Management and Policy Journal, 2(1), 158-164. https://doi.org/10.1108/20408021111162182

McCluskey, T., Burton, B., \& Power, D. (2007). Evidence on Irish financial directors' views about dividends. Qualitative Research in Accounting \& Management, 4(2), 115-132.

MCSC, \& KPDNKK. (2010). Dasar Koperasi Negara 2011-2020. Kuala Lumpur: Malaysian Co-operative 
INTERNATIONAL JOURNAL OF ACADEMIC RESEARCH IN BUSINESS AND SOCIAL SCIENCES

Vol. 10, No. 13, Special Issue: Upstream Research in Business and Management: Towards Socio-Economic Prosperity. 2020, E-ISSN: 2222-6990 @ 2020 HRMARS

Societies Commission (MCSC); Ministry of Domestic Trade, Co-operative and Consumerism (KPDNKK).

Noordin, N., Rajaratnam, S. D., Said, A. M. S., Hanif, M. F., \& Juhan, R. (2012). Dividend and Profit Allocation Practices of Performing Cooperatives in Malaysia. Oñati Socio-Legal Series, 2(2), 156175.

Ofori-Sasu, D., Abor, J. Y., \& Osei, A. K. (2017). Dividend Policy and Shareholders' Value: Evidence from Listed Companies in Ghana. African Development Review, 29(2), 293-304.

Othman, A., \& Kari, F. (2008). Enhancing Co-operative Movement to Achieve Malaysia's Development Goals. In ICA Research Conference (pp. 1-39). Trento: ICA.

Othman, R., Arshad, R., Aris, N. A., \& Arif, S. M. M. (2015). Organizational Resources and Sustained Competitive Advantage of Cooperative Organizations in Malaysia. Procedia - Social and Behavioral Sciences, 170, 120-127. https://doi.org/10.1016/j.sbspro.2015.01.021

Patten, D. M. (1991). Exposure, legitimacy, and social disclosure. Journal of Accounting and Public Policy, 10(4), 297-308. https://doi.org/10.1016/0278-4254(91)90003-3

Redding, L. S. (1997). Firm Size and Dividend Payouts. Journal of Financial Intermediation, 6(3), 224248. https://doi.org/10.1006/jfin.1997.0221

Syrjä, P., Sjögren, H., \& Tuominen, P. (2012). Financial performance and efficiency of consumer cooperatives and limited companies-Agency theoretical approach. Journal of Co-Operative Accounting and Reporting, 1(1), 53-69.

Tariq, Y. Bin., \& Abbas, Z. (2013). Compliance and multidimensional firm performance: Evaluating the efficacy of rule-based code of corporate governance. Economic Modelling, 35, 565-575.

Shbeilat, M. K., Al Harasees, M. N. (2018). Do Listed Companies Need an IFRS Committee Beside Audit Committee? International Journal of Academic Research in Accounting, Finance and Management Sciences 8 (2): 8-18.

Hussin, N., \& Hafit, A. (2018). Green Technology: Awareness among Academic Library Employees. International Journal of Academic Research in Progressive Education and Development, 7(3), 161-177.

Karageorgopoulos, C. (2014). Information Handling Manner As Main Unifying Factor in Community Building. Multilingual Academic Journal of Education and Social Sciences, 2(2), 134-150. 